Bangladesh J. Zool. 49(1): 175-179, 2021

- Scientific note

ISSN: 0304-9027

eISSN: $2408-8455$

\title{
NEW GEOGRAPHICAL RECORD OF SPOTFIN FROGFISH ANTENNATUS NUMMIFER (ACTINOPTERYGII: LOPHIIFORMES: ANTENNARIIDAE) FROM THE COAST OF NORTHERN BAY OF BENGAL, BANGLADESH
}

\author{
Mohammed Rashed Parvej, Md. Farhan Tazim, Al Mamun, Md. Asadujjaman \\ and Mohammad Eusuf Hasan* \\ Marine Fisheries Survey Management Unit, Department of Fisheries \\ CGO Building-2, Agrabad, Chattogram 4100, Bangladesh
}

This study describes a Spotfin Frogfish as a new record from marine waters of Bangladesh in the Northern Bay of Bengal. Based on a single specimen, this fish is identified as Antennatus nummifer (Cuvier, 1817), based on the absence of (or only barely distinguishable) esca, and an immobile third dorsal spine, (characteristic to genus Antennatus), and on the presence of a distinctive large, round and dark basidorsal spot at base of the posterior soft dorsal fin, surrounded by a pale brownish ring.

Frogfishes (Lophiiformes: Antennariidae) are small to moderate fishes having short, deep, globose, and slightly compressed body; a small pore like opercular opening; first dorsal-fin spine free from rest of fin, bearing a welldeveloped terminal bait or esca; and elongated, and leg-like pectoral-fin lobe (Pietsch 1984, 1999; Motomura 2009). This family contains 52 valid species from 14 genera distributed widely in the Indo-Pacific (Fricke et al. 2020). The genus Antennatus is distinguished from closely related Antennarius with the absence of (or only barely distinguishable) esca and an immobile third dorsal spine (Pietsch 1999). So far, a single species of Antennariidae, Antennarius hispidus (Bloch and Schneider, 1801) is known to occur in Bangladesh coast (Hussain 1969). However, an individual of Antennatus nummifer (Cuvier, 1817) was found in a catch of trawl survey conducted by Marine Fisheries Survey Management Unit, Department of Fisheries, Government of Bangladesh. The present study reports this species as a first record from Bangladesh marine water.

A single specimen of frogfish (Figure 1) was captured in a demersal trawl fishing catch (Survey No. 2019203, Survey Station No. 74; Research Vessel Meen Shandhani; Date17 March 2020) conducted at $40 \mathrm{~km}$ south-southwest from Cox's Bazar in Bangladesh territorial zone $\left(21^{\circ} 1.428^{\prime} \mathrm{N}, 92^{\circ} 2.358^{\prime} \mathrm{E}\right)$

\footnotetext{
*Author for correspondence: <hasaneusuf@gmail.com>

(C2021 Zoological Society of Bangladesh DOI: https://doi.org/10.3329/bjz.v49i1.53693
} 


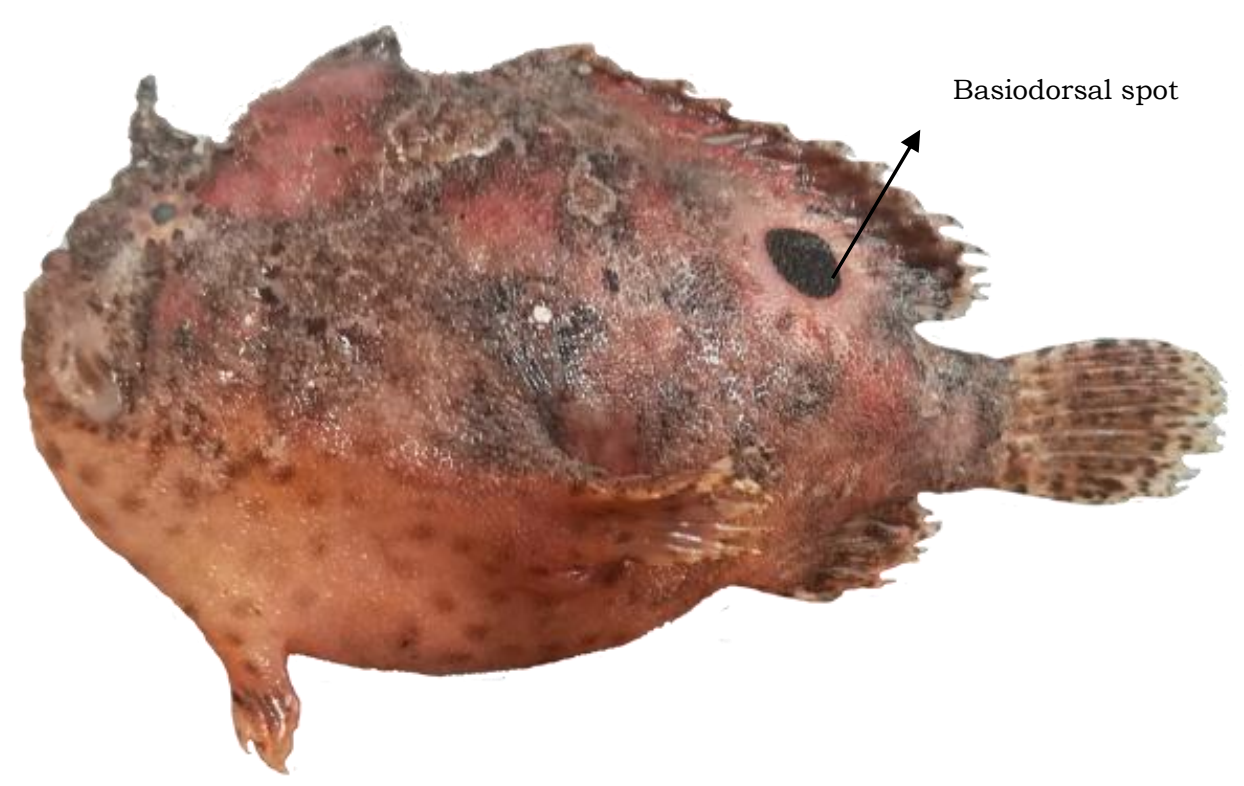

Fig. 1: Antennatus nummifer, $51 \mathrm{~mm}$ SL; lateral view of present study specimen

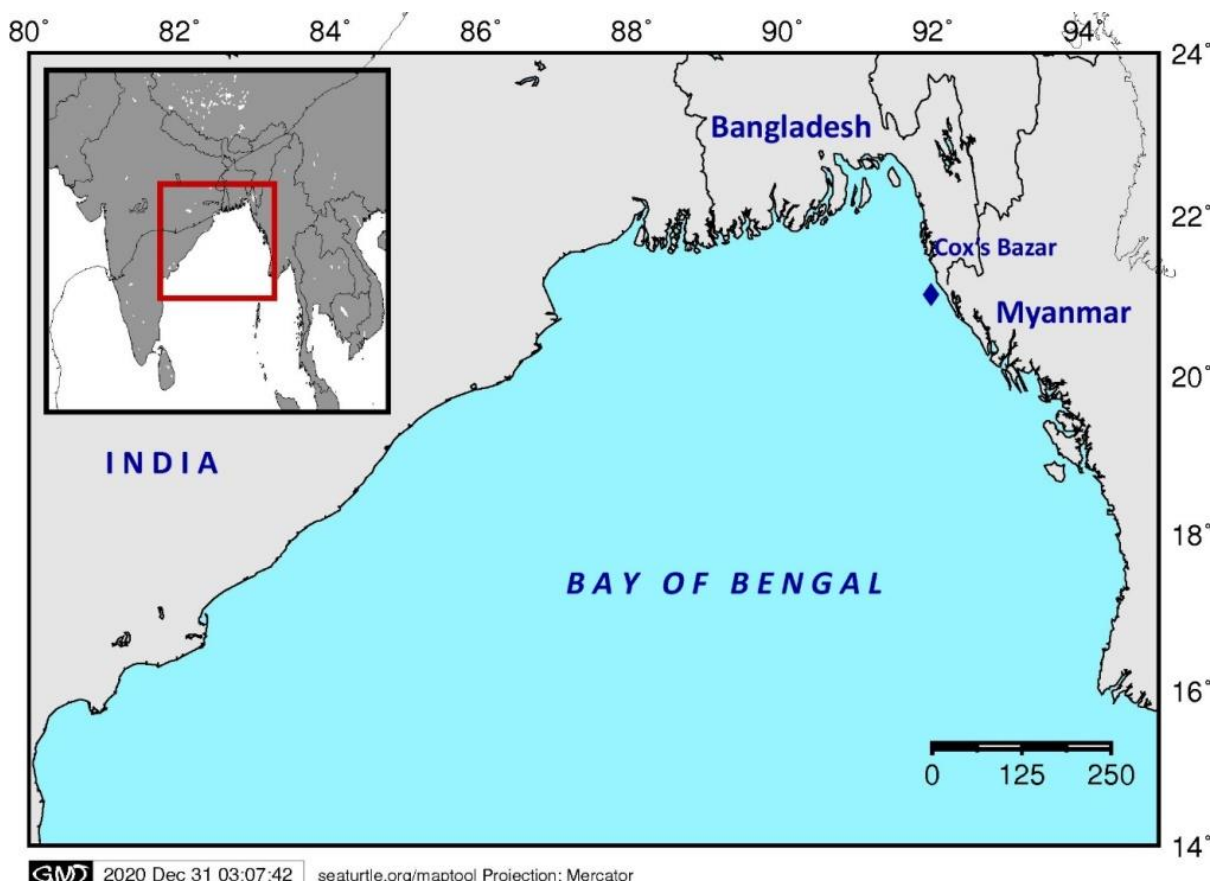

Fig. 2: Collection location of Antennatus nummifer in south-east coast of Bangladesh near Cox's Bazar district (\$). Map source: seaturtle.org/maptool. 
(Figure 2). The demersal trawl net with $30 \mathrm{~mm}$ mesh size was operated at $17 \mathrm{~m}$ depth and at $\sim 3$ knots towing speed. Collected specimen was immediately stored in an onboard freezer and brought to the laboratory of Marine Fisheries Survey Management Unit, Department of Fisheries, Chattogram, Bangladesh for further inspection. Counts and morphometric measurements were taken using a digital Vernier caliper up to $0.1 \mathrm{~mm}$ precision following Hubbs and Lagler (2004).

\section{Taxonomic Position:}

Class: Actinopterygii Goodrich, 1830

Order: Lophiiformes Rafinesque, 1810

Family: Antennariidae Jarocki, 1822

Genus: Antennatus Schultz, 1957

Species: Antennatus nummifer (Cuvier, 1817)

Diagnoses and Descriptions: Body short (51 mm SL, $70 \mathrm{~mm}$ TL, $12 \mathrm{gm}$ ) and globose. Mouth large and oblique with numerous small villiform teeth. Dorsal fin rays $\mathrm{I}+\mathrm{I}+\mathrm{I}$, 12; Pectoral fin rays 11 ; Pelvic fin rays $\mathrm{I}$, 5; Anal fin rays 7; Caudal fin rays 9 . At the base of posterior soft dorsal fin a distinctive large, round and dark basidorsal spot (Ocellus) surrounded by a pale brownish ring. First dorsal spine with a fleshy tentacle, spine base located behind upper jaw symphysis. Second dorsal spine $9.2 \%$ of SL. Illicium short (10.2\% of SL) and almost equal to second dorsal spine. Esca small and round. Skin rough. Posterior end of dorsal fin and anal fin not connected to caudal peduncle. Pectoral-fin rays unbranched. Colour: Body reddish pink to brownish; ventral side pinkish with diffused dark circles. Dorsal, anal and caudal fin with tiny numerous dark spots, more or less evenly placed. All the above characters support the identification of the specimen as Antennatus nummifer according to Motomura (2009: 41) and Psomadakis et al. (2019: 330).

Habitat and Distribution: The present specimen was collected from southeastern inshore areas of Bangladesh coast at $17 \mathrm{~m}$ depth. Elsewhere Antennatus nummifer is reported to inhabit in lagoon and seaward reefs, at least up to $25 \mathrm{~m}$ depth (Psomadakis et al. 2019). It is widely distributed in the Indo-Pacific, from western Indian Ocean (east coast of Africa), to the central Pacific (Hawaiian and Marquesas Islands), and also in eastern Atlantic islands (See Fricke et al. 2020). In the Bay of Bengal region it is reported from Sri Lanka (Munro 1955), east coast of India (Krishnan and Misra 1993, Misra and Krishnan 2003), Andaman Sea coast of Thailand (Motomura 2009), and Myanmar Coast (Psomadakis et al. 2019).

Remarks: Material based ichthyofaunal studies are still limited in Bangladesh marine waters of Bay of Bengal (Hussain 1969; Rahman et al. 2009). However 
some 193 species of finfish have been incorporated in a pictorial catalogue (Singha et al. 2019) which includes a single species of Frogfish, Antennarius hispidus (Bloch and Schneider, 1801). Another frogfish species, Batrachomoeus trispinosus (Günther, 1861), (Family: Batrachoididae, Order: Batrachoidiformes), has been reported from south-west coast of Bangladesh recently (Ahmed et al. 2020). The present study provides occurrence and distribution record of Antennatus nummifer (Cuvier, 1817) in Bangladesh coast proposing a Bangla Name as 'Kalophonta Bengmach' based on a single specimen. More records of occurrence of this species may be found by further surveys.

Acknowledgment: The authors express thanks to Dr. Md. Sharif Uddin (Department of Fisheries, Bangladesh) and all the staffs and crews of Research Vessel Meen Shandhani for their cooperation.

\section{LITERATURE CITED}

AHMED M.S., DATTA S.K., SAHA T., ZHILIK A.A., CHOWDHURY N.J. and AHMED S. 2020. New geographical record of three-spine frogfish, Batrachomoeus trispinosus (Günther 1861) from the River Rupsa, Bangladesh. Bangladesh Journal of Zoology 48(1): 197-202

FRICKE R., ESCHMEYER W.N., VAN DER LAAN R. 2020. Eschmeyer's Catalog of Fishes: Genera, Species, References. Electronic Version: 7 December 2020. Available from: http://researcharchive.calacademy.org/research/ichthyology/catalog/fishcatmain.asp.

HUSSAIN M.M. 1969. Marine and Estuarine Fishes of the North-eastern part of Bay of Bengal. Scientific Researches 7 (1): 26-55

KRISHNAN S., MISHRA S.S. 1993. On a collection of fish from Kakinada-Gopalpur sector of the east coast of India. Records of the Zoological Survey of India 93 (1-2): 201-240

MISHRA S.S., KRISHNAN S. 2003. Marine Fishes of Pondichery and Karaikal. Records of Zoological Survey of India. Occasional Paper No. 216. 52 pp.

MOTOMURA H. 2009. Family account: ANTENNARIIDAE Frogfishes. In: Kimura S., Satapoomin U. and Matsuura K. (eds) Fishes of Andaman Sea, West Coast of Southern Thailand. National Museum of Nature and Science, Tokyo. pp. 40-41

MUNRO I. S. R. 1955. The Marine and Freshwater Fishes of Ceylon. Department of External Affairs.

PIETSCH T.W. 1984. The Genera of Frogfishes (Family Antennariidae). Copeia 1984 (1): 27-44. DOI: $10.2307 / 1445032$

PIETSCH T.W. 1999. ANTENNARIIDAE Frogfishes (also sea mice, anglerfishes). In:Carpenter, K.E. and Niem, V.H. (eds) The Living Marine Resources of the Western Central Pacific. Volume 3. Batoid Fishes, Chimaeras and Bony Fishes Part 1 (Elopidae to Linophrynidae). FAO Species Identification Guide for Fishery Purposes. Rome, FAO. pp. 2013-2015 
PSOMADAKIS P.N., THEIN H., RUSSELL, B.C., TUN M.T. 2019. Field Identification Guide to the Living Marine Resources of Myanmar. FAO Species Identification Guide for Fishery Purposes. Rome, FAO and MOALI. 682 pp.

RAHMAN A.K.A., SIDDIQUI K.U., ISLAM M.A., KABIR S.M.H., AHMED M., AHMED A.T.A., HAQUE E.U., AHMED Z.U., BEGUM Z.N.T., HASAN M.A., KHONDKER M., RAHMAN M.M. (Eds.). 2009. Encyclopedia of Flora and Fauna of Bangladesh. Vol. 24. Marine Fishes. Asiatic Society of Bangladesh, Dhaka.

SINGHA N.K., PARVEJ M.R., UDDIN M.S. AND CHOWDHURY S.R. 2019. Bangladesher Samudrik O Upokulio Matshya Projatir Album (Species Album of Marine and Coastal Fisheries Resources of Bangladesh). Department of Fisheries, Ministry of Fisheries and Livestock. 264 pp.

(Manuscript received on 1 October, 2020 revised on 15 March, 2021) 